\title{
Group Decision Support System for Job Promotion Using the Simple Additive Weighting (SAW) Method
}

\author{
Group Decision Support System Untuk Promosi Jabatan Menggunakan \\ Metode Simple Additive Weighting (SAW)
}

\author{
Muhar Dizani \\ Information System Dept \\ Faculty of Information Technology \\ Universitas Serang Raya \\ Banten, INDONESIA

\section{Sumiati} \\ Informatic Dept \\ Faculty of Information Technology \\ Universitas Serang Raya \\ Banten, INDONESIA

\section{Suherman} \\ Informatic Dept. \\ Faculty of Information Technology \\ Universitas Serang Raya \\ Banten, INDONESIA
}

ZANIMUHARDI@GMAIL.COM

SUMIATI82@YAHOO.COM

SUHERMAN.UNSERA@GMAIL.COM

Corresponding Autor: Zaenal Muttaqin

\begin{abstract}
The Group Decision Support System is a tool used to help group decision makers become faster and more objective. A case study at Serang Raya University is the selection of employees for promotion. The problem is the difficulty in determining which employees will be promoted to fill a certain position and spend a lot of time and how to do the calculation? The research methodology used is system analysis, and calculation of the Simple Additive Weighting (SAW) method. The criteria chosen are based on staffing policies. The decision makers involved were the dean of the faculty, the head of the staffing department and the university's rector. Simple Additive Weighting (SAW) can determine the weight value for each attribute, then proceed with the ranking process that will select the best alternative from a number of alternatives. The results are used to make it easier for users to choose the employees to choose for promotion. This system is expected to help speed up employee decision making to be promoted.
\end{abstract}

Keywords: Group Decision Support System, Job Promotion, Simple Additive Weighting (SAW)

\section{ABSTRAKSI}

Group Decision Support System adalah alat yang digunakan untuk membantu pengambil keputusan kelompok menjadi lebih cepat dan objektif. Sebuah studi kasus pada Universitas Serang Raya adalah 
pemilihan pegawai untuk promosi jabatan. Masalahnya adalah sulitnya menentukan pegawai yang akan dipromosikan untuk mengisi suatu jabatan tertentu dan menghabiskan banyak waktu serta bagaimana melakukan perhitungan? Metodologi penelitian yang digunakan adalah analisis sistem, dan perhitungan metode Simple Additive Weighting (SAW). Kriteria yang dipilih adalah berdasarkan kebijakan bagian kepegawaian. Pengambil keputusan yang terlibat adalah dekan fakultas, kepala bagian kepegawaian dan rektor universitas. Simple Additive Weighting (SAW) dapat menentukan nilai bobot untuk setiap atribut, kemudian dilanjutkan dengan proses perangkingan yang akan menyeleksi aternatif terbaik dari sejumlah alternatif. Hasilnya digunakan untuk memudahkan pengguna dalam memilih pegawai yang akan dipilih untuk dipromosikan. Sistem ini diharapkan dapat membantu dalam mempercepat pengambilan keputusan pegawai untuk dipromosikan.

Keywords: Group Decision Support System, Promosi Jabatan, Simple Additive Weighting (SAW)

\section{Pendahuluan}

Promosi jabatan dibeberapa tempat sering menjadi kesulitan tersendiri karena pengajuan calon kandidat yang bisa menempati jabatan kurang terdefinisi dengan baik. Beberapa faktor penyebab sulitnya melakukan promosi jabatan bagi karyawan yaitu apabila perusahaan memiliki jumlah karyawan yang cukup banyak maka perencanaan jenjang karir setiap karyawan dan pergantian jabatan dalam perusahaan menjadi sulit dan menghabiskan banyak waktu karena tiap personal Human Resource Departement (HRD) belum tentu mengenal tiap karyawan. (Saputra, 2013) Permasalahan seperti inilah yang juga dialami oleh institusi Universitas Serang Raya. Maka untuk meminimalkan kendala tersebut diperlukan suatu sistem pendukung keputusan yang dapat menganalisa beberapa calon yang sesuai dengan profil jabatan yang ada.

Univesitas Serang Raya merupakan salah satu Universitas swasta yang berkembang di Provinsi Banten memiliki potensi Sumber Daya Manusia (SDM) yang tentunya mempengaruhi banyak aspek penentu keberhasilan, khususnya untuk meningkatkan sumber daya manusia yang produktif dan inovatif. Jika SDM dapat diorganisir dengan baik, maka diharapkan institusi dapat menjalankan semua proses kerja dengan baik pula.

Group Decision Support System (GDSS) dipilih karena dapat mendukung aktivitas kelompok, memberikan kecepatan hasil akhir keputusan yang akan diperoleh, setiap pengambil keputusan dapat mengkalkulasikan keputusan secara online dari manapun dan dapat dilakukan secara bersama-sama pada saat yang bersamaan atau tidak bersamaan. Penggunaan sistem pendukung keputusan berbasis kelompok pada penelitian ini adalah untuk meningkatkan kualitas keputusan, sehingga penilaian yang dilakukan lebih objektif, karena pengambilan keputusan tidak dilakukan oleh satu pihak. Banyaknya kriteria yang dipertimbangkan dalam pengambilan keputusan diperlukan suatu perhitungan secara cepat dan mudah.(Ula dan Azhari, $2013: 91$ )

Sebuah Sistem Pendukung Keputusan (SPK) adalah sistem informasi interaktif yang berbasis komputer untuk mendukung pengambilan keputusan. Perkembangan teknik dan model SPK selanjutnya melahirkan konsep Sistem Pendukung Keputusan Kelompok (SPKK) atau Group Decission Suport System (GDSS). GDSS merupakan jenis sistem pendukung pengambilan keputusan dengan desain teknologi kolektif dan kelompok melalui interaksi manusia komputer untuk pengambilan keputusan kelompok secara efektif (Sohail dkk, 2009). Solusi GDSS ditempuh untuk mengatasi permasalahan jika anggota kelompok pengambil keputusan memiliki sudut pandang yang berbeda untuk menggabungkan beberapa preferensi dan menengahi adanya perbedaan ide (Nugrorho et al 2012 : C-67). Banyak metode yang bisa digunakan untuk pendukung keputusan kelompok, salah satunya adalah Simple Additive Weighting (SAW).

Metode SAW sesuai untuk proses pengambilan keputusan karena dapat menentukan nilai bobot untuk setiap atribut, kemudian dilanjutkan dengan proses perangkingan yang akan menyeleksi aternatif terbaik dari sejumlah alternatif. Selain itu, kelebihan dari model SAW dibandingkan dengan model pengambilan keputusan yang lain terletak pada kemampuannya untuk melakukan penilaian secara lebih tepat karena didasarkan pada nilai kriteria dan bobot prefensi yang sudah ditentukan. Total perubahan nilai yang dihasilkan oleh metode SAW lebih banyak sehingga metode SAW sangat relevan untuk menyelesaikan masalah pengambilan keputusan (Darmastuti, 2013:2).

Berdasarkan uraian di atas maka penelitian ini melakukan perancangan Group Decision Support System Untuk Promosi Jabatan dengan pendekatan Metode Simple Additive Weighting (SAW). 


\section{Tinjauan Pustaka}

Penelitian terkait dengan Decission Suport System (DSS) dan Group Decission Support System (GDSS) untuk promosi jabatan bukan merupakan hal yang baru, beberapa penelitian sebelumnya telah memanfaatkan konsep ini. DSS dan GDSS yang dikembangkan untuk promosi jabatan biasanya menggunakan metode SAW, (permatasari 2013, Saputra 2013) dan penentuan dosen berprestasi (Sari et al 2014). Penelitian ini menyimpulkan bahwa metode SAW dapat menyelesaikan masalah pengambilan keputusan dengan multi kriteria untuk penentuan dosen berprestasi dan promosi jabatan.

Beberapa penelitian lain yang memanfaatkan metode SAW yaitu untuk kenaikan jabatan, pemilihan staf pengajar, kelayakan sertifikasi guru, penerimaan beasiswa, rekomendasi pencari kerja dan untuk penilaian proyek sistem informasi (Silalahi 2013, Sinulingga 2014, Rinaldi 2013, Hasanah 2013, Maghfirah 2013, Eniyati 2011, Darmastuti 2013 dan Ma 2011).

Selain menggunakan SAW, penelitian terkait GDSS ada yang menggunakan metode fuzzy untuk pemilihan mahasiswa berprestasi (Hidayat et al 2009). Akan tetapi metode fuzzy akan lebih cocok apabila digunakan untuk sistem pakar seperti pada penelitian Syaukani dan Guritno yang membuat pemodelan Group Decission Suport System untuk mendiagnosis pasien pneumonia pada orang dewasa. Sistem ini dirancang sebagai alat bantu tenaga medis dalam mendiagnosis pasien pneumonia. Sistem diuji dengan cara memasukkan gejala-gejala pneumonia tanpa melibatkan seorang pakar. Hasil penelitian menunjukkan bahwa sistem dapat mendiagnosis penyakit pneumonia (Syaukani dan Gurtino, 2013 : 18). Konsep GDSS juga dimanfaatkan oleh Nugroho dkk untuk system cerdas manajemen gudang, dalam penelitian ini Nugroho dkk menyimpulkan bahwa pendekataan model GDSS yang diusulkan mampu memberikan rekomendasi pemilihan supplier berdasarkan kriteria dan histori (stage) yang pernah terjadi. (Nugroho et al, 2012 : C-74).

\section{Group Decission Suport Sistem (GDSS)}

Sistem Pendukung Keputusan Kelompok (SPKK) adalah sistem berbasis komputer interaktif yang merupakan fasilitas solusi dari masalah semi terstruktur atau tidak terstruktur oleh sekelompok pengambil keputusan. SPKK memiliki beberapa karakteristik utama yaitu:

1) SPKK memiliki tujuan untuk mendukung proses pengambil keputusan kelompok dengan memberikan subproses otomatis, menggunakan alat teknologi informasi.

2) SPKK dirancang khusus sistem informasi, tidak hanya konfigurasi komponen sistem yang sudah ada. Hal ini dapat dirancang untuk menjadi alamat satu jenis masalah atau berbagai keputusan organisasional tingkat kelompok.

3) SPKK mendorong generasi ide, resolusi konflik, dan kebebasan berekspresi. Ini berisi bangunan mekanisme yang mencegah pengembangan perilaku kelompok negatif, seperti konflik destruktif, miskomunikasi, dan kelompok berpikir (Turban, 2011) dalam (Ermatita, $2011: 58$ ).

\section{Simple Additive Weighting (SAW)}

Metode SAW sering juga dikenal sebagai metode penjumlahan terbobot. Konsep dasar metode SAW adalah mencari penjumlahan terbobot dari rating kinerja pada setiap alternatif pada semua atribut. Metode SAW membutuhkan proses normalisasi matriks keputusan (X) ke suatu skala yang dapat diperbandingkan dengan semua rating alternatif yang ada.

Dimana :

$$
r_{i j}= \begin{cases}\frac{x_{i j}}{\max _{i}\left(x_{i j}\right)} & \text { Jika } j \text { adalah keuntungan (benefit) } \\ \frac{x_{i j}}{\min _{i}\left(x_{i j}\right)} & \text { Jika } j \text { adalah biaya (cost) }\end{cases}
$$

$$
\begin{array}{ll}
r_{i j} & : \text { Rating kinerja ternormalisasi } \\
\max _{i j} & : \text { Nilai maksimum dari setiap baris dan } \\
\min _{i j} & : \text { Nilai minimum dari setiap baris dan kolom } \\
x_{i j} & : \text { Baris dan kolom dari matriks }
\end{array}
$$


Dengan $\quad r_{i j}$ adalah rating kinerja ternormalisasi dari alternatif $A_{i}$ pada atribut $\mathrm{C}_{\mathrm{j}} ; \mathrm{i}=$ $1,2,3, \ldots \mathrm{m}$ dan $j=1,2,3, \ldots \mathrm{n}$. Nilai preferensi alternatif $\left(V_{i}\right)$ diberikan sebagai berikut :

$$
V_{i}=\sum_{j=1}^{n} w_{j} r_{i j}
$$

Keterangan :

$$
\begin{array}{ll}
\mathrm{CVw} & =\text { Indeks Williamson } \\
\mathrm{fi} & =\text { Jumlah penduduk kabupaten/kota (jiwa) } \\
\mathrm{n} & =\text { Jumlah penduduk Provinsi (jiwa) } \\
\mathrm{Yi} & =\text { PDRB per kapita kabupaten/kota (Rupiah) } \\
\mathrm{y} & =\text { PDRB per kapita rata-rata Provinsi (Rupiah) }
\end{array}
$$

\section{Metodologi Penelitian}

Penelitian ini diawali dengan identifikasi permasalahan yang dihadapi objek penelitian. Kemudian dilakukan pemilihan permasalahan yang dapat diselesaikan. Langkah berikutnya adalah melakukan pengumpulan data yang dibutuhkan untuk analisis pendukung keputusan kelompok. Tahap berikutnya adalah menganalisis data menggunakan pendekatan simple additive weighting (SAW), kemudian diimplementasikan ke dalam aplikasi. Tahap terakhir adalah pengujian dan publikasi hasil penelitian.

\section{Hasil dan Pembahasan}

Berikut adalah perhitungan Metode Simple Additive Weighting (SAW) untuk promosi jabatan yang diimplementasikan dalam aplikasi pendukung keputusan kelompok.
Alternatif
$\mathrm{A} 1=$ Pegawai $\mathrm{A}$
$\mathrm{A} 2$ = Pegawai $\mathrm{B}$
A3 = Pegawai $\mathrm{C}$
A4 = Pegawai D
A5 $=$ Pegawai E
$\mathrm{A} 6=$ Pegawai $\mathrm{F}$

Kriteria

Berikut ini empat kriteria yang digunakan dalam proses penghitungan promosi jabatan :

$\mathrm{C} 1=$ Normatif

$\mathrm{C} 2=$ Prestasi Kerja

C3 = Tanggung Jawab

$\mathrm{C} 4=$ Prakarsa

Pembobotan Keputusan

Menentukan skala likert atau tingkat kepentingan dari setiap indikator dengan nilai:

Sangant Kurang $=1$

$\begin{array}{ll}\text { Kurang } & =2 \\ \text { Cukup } & =3 \\ \text { Baik } & =4 \\ \text { Sangat Baik } & =5\end{array}$

Bobot preferensi atau tingkat kepentingan dari setiap indikator, diberikan nilai pada setiap indikator $(1,1,1,1)$, dimana penentuan bobot preferensi atau tingkat kepentingan ini diambil dari kebijakan Bagian kepegawaian Universitas Serang Raya pada perhitungan manual. Berikut adalah skor penilaian yang diterapkan Bagian kepegawaian Universitas Serang Raya pada perhitungan manual:

$90-100=$ Sangan baik

$76-89=$ Baik 
$60-75 \quad=$ Sedang

$0-59 \quad=$ Kurang

Pada kasus ini ada 3 (tiga) pengambil keputusan yaitu dekan fakultas, kabiro kepegawaian dan rektor. Sebagai contoh perhitungan setelah dilakukan penilaian didapatkan skor pada Tabel 1 yang merupakan hasil penilaian yang dilakukan oleh dekan fakultas.

Tabel 1. Alternativ dan nilai dari dekan

\begin{tabular}{ccccc}
\hline \multirow{2}{*}{ Alternativ } & \multicolumn{4}{c}{ Kriteria } \\
\cline { 2 - 5 } & C1 & C2 & C3 & C4 \\
\hline \hline A1 & 65 & 80 & 70 & 75 \\
\hline A2 & 80 & 65 & 85 & 70 \\
\hline A3 & 80 & 70 & 75 & 65 \\
\hline A4 & 75 & 80 & 65 & 75 \\
\hline A5 & 65 & 60 & 70 & 85 \\
\hline A6 & 80 & 65 & 70 & 85 \\
\hline \hline
\end{tabular}

Menghitung Matrix Normalisasi

$r_{11}=\frac{65}{\max (65 ; 80 ; 80 ; 75 ; 65 ; 80)}=\frac{65}{80}=0.81$

$r_{21}=\frac{80}{\max (65 ; 80 ; 80 ; 75 ; 65 ; 80)}=\frac{80}{80}=1$

$r_{31}=\frac{80}{\max (65 ; 80 ; 80 ; 75 ; 65 ; 80)}=\frac{80}{80}=1$

$r_{41}=\frac{75}{\max (65 ; 80 ; 80 ; 75 ; 65 ; 80)}=\frac{75}{80}=0.94$

$r_{51}=\frac{65}{\max (65 ; 80 ; 80 ; 75 ; 65 ; 80)}=\frac{65}{80}=0.81$

$r_{\mathrm{B} 1}=\frac{80}{\max (65 ; 80 ; 80 ; 75 ; 65 ; 80)}=\frac{80}{80}=1$

$r_{12}=\frac{80}{\max (80 ; 65 ; 70 ; 80 ; 60 ; 65)}=\frac{80}{80}=1$

$r_{22}=\frac{65}{\max (80 ; 65 ; 70 ; 80 ; 60 ; 65)}=\frac{65}{80}=0.81$

$r_{32}=\frac{70}{\max (80 ; 65 ; 70 ; 80 ; 60 ; 65)}=\frac{70}{80}=0.88$

$r_{42}=\frac{80}{\max (80 ; 65 ; 70 ; 80 ; 60 ; 65)}=\frac{80}{80}=1$

$r_{52}=\frac{60}{\max (80 ; 65 ; 70 ; 80 ; 60 ; 65)}=\frac{60}{80}=0.75$ 


$$
\begin{aligned}
& r_{\mathrm{B} 2}=\frac{65}{\max (80 ; 65 ; 70 ; 80 ; 60 ; 65)}=\frac{65}{80}=0,81 \\
& r_{13}=\frac{70}{\max (70 ; 85 ; 75 ; 65 ; 70 ; 70)}=\frac{70}{85}=0.82 \\
& r_{23}=\frac{85}{\max (70 ; 85 ; 75 ; 65 ; 70 ; 70)}=\frac{85}{85}=1 \\
& r_{33}=\frac{75}{\max (70 ; 85 ; 75 ; 65 ; 70 ; 70)}=\frac{75}{85}=0.88 \\
& r_{43}=\frac{65}{\max (70 ; 85 ; 75 ; 65 ; 70 ; 70)}=\frac{65}{85}=0.76 \\
& r_{53}=\frac{70}{\max (70 ; 85 ; 75 ; 65 ; 70 ; 70)}=\frac{70}{85}=0.82 \\
& r_{\mathrm{B} 3}=\frac{70}{\max (70 ; 85 ; 75 ; 65 ; 70 ; 70)}=\frac{70}{85}=0.82 \\
& r_{14}=\frac{75}{\max (75 ; 70 ; 65 ; 75 ; 85 ; 85)}=\frac{75}{85}=0.88 \\
& r_{24}=\frac{70}{\max (75 ; 70 ; 65 ; 75 ; 85 ; 85)}=\frac{70}{85}=0.82 \\
& r_{34}=\frac{65}{\max (75 ; 70 ; 65 ; 75 ; 85 ; 85)}=\frac{65}{85}=0.76 \\
& r_{44}=\frac{75}{\max (75 ; 70 ; 65 ; 75 ; 85 ; 85)}=\frac{75}{85}=0.88 \\
& r_{54}=\frac{85}{\max (75 ; 70 ; 65 ; 75 ; 85 ; 85)}=\frac{85}{85}=1 \\
& r_{\mathrm{B5}}=\frac{85}{\max (75 ; 70 ; 65 ; 75 ; 85 ; 85)}=\frac{85}{85}=1
\end{aligned}
$$

Hasil Matrik Normalisasi :

$\begin{array}{cccc}0.81 & 1 & 0.82 & 0.88 \\ 1 & 0.81 & 1 & 0.82 \\ 1 & 0.88 & 0.88 & 0.76 \\ 0.94 & 1 & 0.76 & 0.88 \\ 0.81 & 0.75 & 0.82 & 1 \\ 1 & 0.81 & 0.82 & 1\end{array}$

Proses perangkingan bobot dengan cara mengkalikan hasil matrik normalisasi dengan bobot kriteria :

$$
\begin{aligned}
& \mathrm{V} 1=1(0.81)+1(1)+1(0.82)+1(0.88)=3.51 \\
& \mathrm{~V} 2=1(1)+1(0.81)+1(1)+1(0.82)=3.63 \\
& \mathrm{~V} 3=1(1)+1(0.88)+1(0.88)+1(0.76)=3.52
\end{aligned}
$$


$\mathrm{V} 4=1(0.94)+1(0.75)+1(0.82)+1(1)=3.58$

$\mathrm{V} 5=1(0.81)+1(0.75)+1(0.82)+1(1)=3.38$

$\mathrm{V} 6=1(1)+1(0.81)+1(0.82)+1(1)=3.62$

Berdasarkan hasil perhitungan V2 adalah kandidat terpilih dari dekan fakultas. Berikut adalah penilaian yang dilakukan oleh kabiro kepegawaian seperti pada Tabel 2.

Tabel 2. Alternativ dan nilai dari kabiro kepegawaian

\begin{tabular}{ccccc}
\hline \multirow{2}{*}{ Alternativ } & \multicolumn{4}{c}{ Kriteria } \\
\cline { 2 - 5 } & C1 & C2 & C3 & C4 \\
\hline \hline A1 & 55 & 70 & 65 & 60 \\
\hline A2 & 70 & 60 & 65 & 75 \\
\hline A3 & 70 & 65 & 60 & 80 \\
\hline A4 & 85 & 55 & 70 & 60 \\
\hline A5 & 60 & 80 & 85 & 55 \\
\hline A6 & 65 & 70 & 55 & 80 \\
\hline \hline
\end{tabular}

Menghitung Matrix Normalisasi

$r_{11}=\frac{55}{\max (55 ; 70 ; 70 ; 85 ; 60 ; 65)}=\frac{55}{85}=0.65$

$r_{21}=\frac{70}{\max (55 ; 70 ; 70 ; 85 ; 60 ; 65)}=\frac{70}{85}=0.82$

$r_{31}=\frac{70}{\max (55 ; 70 ; 70 ; 85 ; 60 ; 65)}=\frac{70}{85}=0.82$

$r_{41}=\frac{85}{\max (55 ; 70 ; 70 ; 85 ; 60 ; 65)}=\frac{85}{80}=1$

$r_{51}=\frac{60}{\max (55 ; 70 ; 70 ; 85 ; 60 ; 65)}=\frac{60}{85}=0.71$

$r_{\mathrm{B} 1}=\frac{65}{\max (55 ; 70 ; 70 ; 85 ; 60 ; 65)}=\frac{65}{85}=0.76$

$r_{12}=\frac{70}{\max (70 ; 60 ; 65 ; 55 ; 80 ; 70)}=\frac{70}{80}=0.88$

$r_{22}=\frac{60}{\max (70 ; 60 ; 65 ; 55 ; 80 ; 70)}=\frac{60}{80}=0.75$

$r_{32}=\frac{65}{\max (70 ; 60 ; 65 ; 55 ; 80 ; 70)}=\frac{65}{80}=0.81$

$r_{42}=\frac{55}{\max (70 ; 60 ; 65 ; 55 ; 80 ; 70)}=\frac{55}{80}=0.69$

$r_{52}=\frac{80}{\max (70 ; 60 ; 65 ; 55 ; 80 ; 70)}=\frac{80}{80}=1$ 


$$
\begin{aligned}
& r_{\mathrm{B} 2}=\frac{70}{\max (70 ; 60 ; 65 ; 55 ; 80 ; 70)}=\frac{70}{80}=0.88 \\
& r_{13}=\frac{65}{\max (65 ; 65 ; 60 ; 70 ; 85 ; 55)}=\frac{65}{85}=0.67 \\
& r_{23}=\frac{65}{\max (65 ; 65 ; 60 ; 70 ; 85 ; 55)}=\frac{65}{85}=0.67 \\
& r_{33}=\frac{60}{\max (65 ; 65 ; 60 ; 70 ; 85 ; 55)}=\frac{60}{85}=0.71 \\
& r_{43}=\frac{70}{\max (65 ; 65 ; 60 ; 70 ; 85 ; 55)}=\frac{70}{85}=0.82 \\
& r_{54}=\frac{85}{\max (60 ; 75 ; 80 ; 60 ; 55 ; 80 ; 65 ; 80)}=\frac{55}{80}=0.69 \\
& r_{54}=\frac{85}{\max (60 ; 75 ; 80 ; 60 ; 55 ; 80)}=\frac{60}{80}=0.75 \\
& r_{24}=\frac{85}{\max (60 ; 75 ; 80 ; 60 ; 55 ; 80)}=\frac{75}{80}=0.94 \\
& r_{14}=\frac{85}{\max (60 ; 75 ; 80 ; 60 ; 55 ; 80)}=\frac{60}{80}=0.75 \\
& r_{63}=\frac{55}{\max (65 ; 65 ; 60 ; 70 ; 85 ; 55)}=\frac{55}{85}=0.65
\end{aligned}
$$

Hasil Matrik Normalisasi :

$\begin{array}{cccc}0.65 & 0.88 & 0.76 & 0.75 \\ 0.82 & 0.75 & 0.76 & 0.94 \\ 0.82 & 0.81 & 0.71 & 1 \\ 1 & 0.69 & 0.82 & 0.75 \\ 0.71 & 1 & 1 & 0.69 \\ 0.67 & 0.88 & 0.65 & 1\end{array}$

Proses perangkingan bobot dengan cara mengkalikan hasil matrik normalisasi dengan bobot kriteria :

$$
\begin{aligned}
& \mathrm{V} 1=1(0.65)+1(0.88)+1(0.76)+1(0.75)=3.04 \\
& \mathrm{~V} 2=1(0.82)+1(0.75)+1(0.76)+1(0.94)=3.28 \\
& \mathrm{~V} 3=1(0.82)+1(0.81)+1(0.71)+1(1)=3.34
\end{aligned}
$$


$\mathrm{V} 4=1(1)+1(0.69)+1(0.82)+1(0.75)=3.26$

$\mathrm{V} 5=1(0.71)+1(1)+1(1)+1(0.69)=3.39$

$\mathrm{V} 6=1(0.67)+1(0.88)+1(0.65)+1(1)=3.29$

Berdasarkan hasil perhitungan V5 adalah kandidat terpilih dari kabiro kepegawaian. Berikut adalah penilaian yang dilakukan oleh rektor seperti diperlihatkan pada Tabel 3.

Tabel 3. Alternativ dan nilai dari rektor

\begin{tabular}{ccccc}
\hline \multirow{2}{*}{ Alternativ } & \multicolumn{4}{c}{ Kriteria } \\
\cline { 2 - 5 } & $\mathbf{C 1}$ & $\mathbf{C 2}$ & $\mathbf{C 3}$ & $\mathbf{C 4}$ \\
\hline \hline A1 & 70 & 80 & 75 & 70 \\
\hline A2 & 75 & 70 & 80 & 60 \\
\hline A3 & 60 & 85 & 75 & 70 \\
\hline A4 & 80 & 70 & 60 & 75 \\
\hline A5 & 65 & 75 & 80 & 70 \\
\hline A6 & 65 & 80 & 75 & 60 \\
\hline \hline
\end{tabular}

Menghitung Matrix Normalisasi

$r_{11}=\frac{70}{\max (70 ; 75 ; 60 ; 80 ; 65 ; 65)}=\frac{70}{80}=0.88$

$r_{21}=\frac{75}{\max (70 ; 75 ; 60 ; 80 ; 65 ; 65)}=\frac{75}{80}=0.94$

$r_{31}=\frac{60}{\max (70 ; 75 ; 60 ; 80 ; 65 ; 65)}=\frac{60}{80}=0.75$

$r_{41}=\frac{80}{\max (70 ; 75 ; 60 ; 80 ; 65 ; 65)}=\frac{80}{80}=1$

$r_{51}=\frac{65}{\max (70 ; 75 ; 60 ; 80 ; 65 ; 65)}=\frac{65}{80}=0.81$

$r_{\mathrm{B} 1}=\frac{65}{\max (70 ; 75 ; 60 ; 80 ; 65 ; 65)}=\frac{65}{80}=0.81$

$r_{12}=\frac{80}{\max (80 ; 70 ; 85 ; 70 ; 75 ; 80)}=\frac{80}{85}=0.94$

$r_{22}=\frac{70}{\max (80 ; 70 ; 85 ; 70 ; 75 ; 80)}=\frac{70}{85}=0.82$

$r_{32}=\frac{85}{\max (80 ; 70 ; 85 ; 70 ; 75 ; 80)}=\frac{85}{85}=1$

$r_{42}=\frac{70}{\max (80 ; 70 ; 85 ; 70 ; 75 ; 80)}=\frac{70}{85}=0.82$

$r_{52}=\frac{75}{\max (80 ; 70 ; 85 ; 70 ; 75 ; 80)}=\frac{75}{85}=0.88$ 


$$
\begin{aligned}
& r_{\mathrm{B} 2}=\frac{80}{\max (80 ; 70 ; 85 ; 70 ; 75 ; 80)}=\frac{80}{85}=0.94 \\
& r_{13}=\frac{75}{\max (75 ; 80 ; 75 ; 60 ; 80 ; 75)}=\frac{75}{80}=0.94 \\
& r_{23}=\frac{80}{\max (75 ; 80 ; 75 ; 60 ; 80 ; 75)}=\frac{80}{80}=1 \\
& r_{33}=\frac{75}{\max (75 ; 80 ; 75 ; 60 ; 80 ; 75)}=\frac{75}{80}=0.94 \\
& r_{43}=\frac{60}{\max (75 ; 80 ; 75 ; 60 ; 80 ; 75)}=\frac{60}{80}=0.75 \\
& r_{53}=\frac{80}{\max (75 ; 80 ; 75 ; 60 ; 80 ; 75)}=\frac{80}{80}=1 \\
& r_{\mathrm{B} 3}=\frac{75}{\max (75 ; 80 ; 75 ; 60 ; 80 ; 75)}=\frac{75}{80}=0.94 \\
& r_{14}=\frac{70}{\max (70 ; 60 ; 70 ; 75 ; 70 ; 60)}=\frac{70}{75}=0.93 \\
& r_{24}=\frac{60}{\max (70 ; 60 ; 70 ; 75 ; 70 ; 60)}=\frac{60}{75}=0.80 \\
& r_{34}=\frac{70}{\max (70 ; 60 ; 70 ; 75 ; 70 ; 60)}=\frac{70}{75}=0.93 \\
& r_{44}=\frac{75}{\max (70 ; 60 ; 70 ; 75 ; 70 ; 60)}=\frac{75}{75}=1 \\
& r_{54}=\frac{70}{\max (70 ; 60 ; 70 ; 75 ; 70 ; 60)}=\frac{70}{75}=0.93 \\
& r_{\mathrm{E} 4}=\frac{6 \mathrm{D}}{\max (7 \mathrm{D} ; 6 \mathrm{D} ; 7 \mathrm{D} ; 75 ; 7 \mathrm{D} ; 6 \mathrm{D})}=\frac{6 \mathrm{D}}{75}=0.80
\end{aligned}
$$

Hasil Matrik Normalisasi :

$\begin{array}{cccc}0.88 & 0.94 & 0.94 & 0.93 \\ 0.94 & 0.82 & 1 & 0.80 \\ 0.75 & 1 & 0.94 & 0.93 \\ 1 & 0.82 & 0.75 & 1 \\ 0.81 & 0.88 & 1 & 0.93 \\ 0.81 & 0.94 & 0.94 & 0.80\end{array}$

Proses perangkingan bobot dengan cara mengkalikan hasil matrik normalisasi dengan bobot kriteria :

$$
\begin{aligned}
& \mathrm{V} 1=1(0.88)+1(0.94)+1(0.94)+1(0.93)=3.69 \\
& \mathrm{~V} 2=1(0.94)+1(0.82)+1(1)+1(0.80)=3.56 \\
& \mathrm{~V} 3=1(0.75)+1(1)+1(0.94)+1(0.93)=3.62 \\
& \mathrm{~V} 4=1(1)+1(0.82)+1(0.75)+1(1)=3.57
\end{aligned}
$$


$\mathrm{V} 5=1(0.81)+1(0.88)+1(1)+1(0.93)=3.63$

$\mathrm{V} 6=1(0.81)+1(0.94)+1(0.94)+1(0.80)=3.49$

Berdasarkan hasil perhitungan V1 adalah kandidat terpilih dari rector. Setelah dilakukan perhitungan dari 3 (tiga) pemilih tersebut maka diperoleh 3 kandidat terpilih yaitu V1, V2 dan V5. Berikut adalah proses perhitungan GDSS dengan mengambil bobot nilai rata-rata dari setiap kandidat

A1

$C 1=\frac{65+55+70}{3}=\frac{190}{3}=63.33$

$C 2=\frac{80+70+80}{3}=\frac{230}{3}=76.67$

$C 3=\frac{70+65+75}{3}=\frac{210}{3}=70$

$C 4=\frac{75+60+70}{3}=\frac{205}{3}=68.33$

A2

$1=\frac{80+70+75}{3}=\frac{225}{3}=75$

$C 2=\frac{65+60+70}{3}=\frac{195}{3}=65$

$C 3=\frac{85+65+80}{3}=\frac{230}{3}=76.67$

$C 4=\frac{70+75+60}{3}=\frac{205}{3}=68.33$

A5

$C 1=\frac{65+60+65}{3}=\frac{190}{3}=63.33$

$C 2=\frac{60+80+75}{3}=\frac{215}{3}=71.67$

$C 3=\frac{70+85+80}{3}=\frac{235}{3}=78.33$

$C 4=\frac{35+55+7 D}{3}=\frac{21 D}{3}=70$ 
DiZANi DKK, GROUP DeCision SUPPORT SySTEM FOR Job Promotion...

Tabel 4. Alternativ dan nilai GDSS

\begin{tabular}{ccccc}
\hline \multirow{2}{*}{ Alternativ } & \multicolumn{4}{c}{ Kriteria } \\
\cline { 2 - 5 } & C1 & C2 & C3 & C4 \\
\hline \hline A1 & 63.33 & 76.67 & 70 & 68.33 \\
\hline A2 & 75 & 65 & 76.67 & 68.33 \\
\hline A5 & 63.33 & 71.67 & 78.33 & 70 \\
\hline \hline
\end{tabular}

Menghitung Matrix Normalisasi

$r_{11}=\frac{63.33}{\max (63.33 ; 75 ; 63.33)}=\frac{63.33}{75}=0.84$

$r_{21}=\frac{75}{\max (63.33 ; 75 ; 63.33)}=\frac{75}{75}=1$

$r_{11}=\frac{63.33}{\max (63.33 ; 75 ; 63.33)}=\frac{63.33}{75}=0.84$

$r_{12}=\frac{76.67}{\max (76.67 ; 65 ; 71.67)}=\frac{76.67}{76.67}=1$

$r_{22}=\frac{65}{\max (76.67 ; 65 ; 71.67)}=\frac{65}{76.67}=0.85$

$r_{32}=\frac{71.76}{\max (76.67 ; 65 ; 71.67)}=\frac{71.76}{76.67}=0.93$

$r_{13}=\frac{70}{\max (70 ; 76.67 ; 78.33)}=\frac{70}{78.33}=0.89$

$r_{23}=\frac{76.67}{\max (70 ; 76.67 ; 78.33)}=\frac{76.67}{78.33}=0.98$

$r_{33}=\frac{78.33}{\max (70 ; 76.67 ; 78.33)}=\frac{78.33}{78.33}=1$

$r_{14}=\frac{68.33}{\max (68.33 ; 68.33 ; 70)}=\frac{68.33}{70}=0.98$

$r_{24}=\frac{68.33}{\max (68.33 ; 68.33 ; 70)}=\frac{68.33}{70}=0.98$

$r_{34}=\frac{7 \mathrm{D}}{\operatorname{ma} x(68.37 ; 68.33 ; 7 \mathrm{D})}=\frac{7 \mathrm{D}}{7 \mathrm{D}}=1$

Hasil Matrik Normalisasi GDSS

$\begin{array}{cccc}0.84 & 1 & 0.89 & 0.98 \\ 1 & 0.85 & 0.98 & 0.98 \\ 0.84 & 0.93 & 1 & 1\end{array}$

Proses perangkingan bobot dengan cara mengkalikan hasil matrik normalisasi dengan bobot kriteria :

$\mathrm{V} 1=1(0.84)+1(1)+1(0.89)+1(0.98)=3.71$ 
$\mathrm{V} 2=1(1)+1(0.85)+1(0.98)+1(0.98)=3.80$

$\mathrm{V} 5=1(0.84)+1(0.93)+1(1)+1(1)=3.78$

Berdasarkan hasil perhitungan V2 memperoleh nilai tertinggi jadi pegawai B adalah pegawai terpilih untuk dipromosikan

\section{Kesimpulan}

Hasil penelitian memperlihatkan bahwa dari delapan kota / kabupaten di Provinsi Banten hampir sebagian besar masuk ke dalam status ketimpangan level rendah. Artinya bahwa semua kabupaten / kota pada dasarnya sudah mengalami perkembangan pembangunan yang cukup signifikan.

\section{References}

Asghar, Sohail et al, 2009, A Contemplation of Group Decision Support Systems, Department of Computer Science Mohammad Ali Jinnah University, Islamabad, Pakistan

Darmastuti, Destriyana, 2013, Implementasi Metode Simple Additive Weighting (Saw) Dalam Sistem Informasi Lowongan Kerja Berbasis Web Untuk Rekomendasi Pencari Kerja Terbaik. Universitas Tanjungpura. Pontianak.

Eniyati, Sri, 2011, Perancangan Sistem Pendukung Pengambilan Keputusan untuk Penerimaan Beasiswa dengan Metode SAW (Simple Additive Weighting). Universitas Stikubank. Semarang.

Ermatita et al, 2011, Electre Methods In Solving Group Decision Support System Bioinformatics On Gene Mutation Detection Simulation. International Journal of Computer Science \& Information Technology (IJCSIT), Vol 3, No 1, Universitas Gajah Mada, Yogyakarta.

Hasanah, Rina, 2013, Sistem Pendukung Keputusan Untuk Menentukan Penerima Beasiswa Dengan Metode Simple Additive Weighting (Saw). STMIK Budi Darma. Medan.

Lestari, Endang, 2009, Analisa Sistem Pendukung Keputusan untuk Proses Kenaikan Jabatan pada PT. X. Universitas Sriwijaya. Palembang.

Ma, Jian et al, 2011, Group Decision Support System for Assessment of Projects in Information Systems. University of Hong Kong. Hong Kong.

Maghfirah, 2013, Sistem Pendukung Keputusan Untuk Menentukan Penerima Beasiswa Bagi Siswa Sd Salman Al Farisi 2 Yogyakarta Menggunakan Metode Simple Additive Weighting (Saw). Amikom yogyakarta. Yogyakarta.. 